\title{
Gender specific effects of financial and housework contributions on depression: A multi-actor study among three household types in Belgium
}

\author{
Rozemariun Dereuddre, Sarah Missinne, Veerle Buffel and Piet Bracke \\ Department of Sociology, Health and Demographic Research, University of Ghent, \\ Ghent, Belgium
}

Aвsтract: Studies that focus on the effects of both the division of household chores and of financial contributions on the mental health of couples are scarce. This paper expands on previous research by paying attention to the variation of this relationship among three types of households: Male breadwinner, one-and-a-half-earner and dual-earner. Using paired data from the 10th wave of the Panel Study of Belgian Households, collected in 2001, we perform separate linear regressions for men $(N=1054)$ and women $(N=1054)$. The results suggest that in one-and-a-half-earner households, women's employment has a negative effect on their partner's depression level and that in dual-earner households, the effect of women's employment is only negative if men are not the major breadwinner. Crossover effects of depression between partners seem to mediate part of the aforementioned associations.

KeYwords: sociology, depression, type of household, financial contributions, housework, crossover effect

$\mathrm{M}$ any advanced economies are in various stages of the transition from a predominantly male breadwinner system to a primarily dual-earner system. This transition and its consequences have received considerable research attention. However, within the domain of the division of labour and its relationship with mental health, studies paying attention to the variation among dual-earner households are scarce (Ferree, 1991; Stier \& Lewin-Epstein, 2000). Although the majority of employed women still works full-time, during the past two decades a growing proportion of the female labour force began to engage in part-time employment (Anxo, Fagan, Smith, Letablier, \& Perraudin, 2007; Stier \& Lewin-Epstein, 2000). In 2011, $43.4 \%$ of all employed Belgian women worked part-time, compared with an average of $32.2 \%$ for the whole of the European Union (Eurostat, 2012). In Belgium, the right to request parttime working hours is strong compared with other European countries, especially those in Southern Europe (Anxo et al., 2007). The most common way of working part-time in Belgium is half-time jobs of around 15-29 hours a week (Hakim, 1997), based on working full-time for fixed days of the week with the other days off (Anxo et al., 2007). Because of this large proportion of part-time employment, both dual-earner households (with both the man and woman working full-time) and one-and-a-half-earner households (a variation of the male breadwinner model, where the man remains the main breadwinner and the woman works part-time) are strongly represented in Belgium (Flanders) (Aboim, 2010; Franco \& Winqvist, 2002).

These changing household systems have affected women's financial contribution to the household income and the organisation of housework (Coltrane, 2000; Shelton \& John, 1996; Stier \& Lewin-Epstein, 2000). First, an independent income increases women's power position within the household with regard to bargaining about housework tasks, responsibilities and decision-making. Although women are usually the secondary wage earner, even in dualearner households (Parkman, 2004), researchers argue that only full-time employment, compared with part-time employment, contributes to equality (Stier \& Lewin-Epstein, 2000). Parttime employment implies a lower income and inferior prospects in the labour market, and consequently does not serve as a legitimate basis for bargaining about the division of household tasks. In this regard, Zelizer (1989) criticises the idea of strictly and objectively defined money. Instead, the meaning of money is a social and cultural construction. Historically, women's income was seen as a less fundamental type of money than men's, because the latter were supposed to be 
the 'real providers.' The implication is that as long as couples see the man as the main breadwinner - which can especially be expected in one-and-a-half-earner households - the woman's income will be treated as different and less important, which will prevent the increase of her marital power in direct relation to her earnings (Mirowsky, 1985; Vogler, 1998).

Second, as a result of time limitations due to women's labour-market activities, men are compelled to participate more in household tasks (Stier \& Lewin-Epstein, 2000). Barnett and Shen (1997) point to the fact that housework is a complex construct. In contrast with the common distinction between male and female tasks (Coltrane, 2000; Lachance-Grzela \& Bouchard, 2010), they claim that men as well as women do both. Therefore, they based their distinction on an aspect of job control, namely 'schedule control' or the ability 'to perform tasks on a schedule independent of another's personal needs' (Barnett \& Shen, 1997, p. 406). On the one hand there are those tasks that have to be performed on a regular basis ('low-schedule-control household tasks') and on the other hand, those tasks that do not have to be performed so routinely ('highschedule-control household tasks') (Barnett \& Shen, 1997). Only tasks low in schedule control have been shown to be related to psychological distress. A lack of schedule control can lead to disruption and has been identified as a potential correlate of distress. In this study, we explicitly acknowledge these different types of household tasks and consider the role of both low and highschedule-control housework.

In response to these evolutions, previous research points towards the implications of paid and unpaid labour for personal and partner's (mental) health. Two types of studies can be distinguished (Kalmijn \& Monden, 2011). The first type focuses on the effect of paid work on mental health. Two aspects of paid work are considered: Being employed and earning money. Employment preserves or improves psychological well-being for both men and women (Aube, Fleury, \& Smetana, 2000; Boye, 2011; Kalmijn \& Monden, 2011; Ross \& Mirowsky, 1995). However, working part-time is associated with a lower sense of control in comparison with working full-time, because it is generally more routine and less autonomous (Ross \& Wright, 1998). It also appears that women's employment is detrimental to men's depression scores, although this relationship may be mediated by, for instance, the ethnicity of the couple (Kessler \& McRae, 1982; Orbuch \& Custer, 1995). In this paper, employment status is considered at the marriage level and referred to as the type of household (infra). Increased income appears beneficial for both men's and women's psychological well-being (Rogers \& DeBoer, 2001). Earning less, by contrast, is considered as an indicator of relative disadvantage, leading to depression via feelings of powerlessness or lack of control (Mirowsky, 1985). The fact that women are still likely to hold work positions with lower pay than men, which involves higher financial dependence and lower marital power, may have negative implications for their own mental health (Aube et al., 2000). For men, the increase in women's relative earnings is associated with lower well-being (Rogers \& DeBoer, 2001). In this paper, earnings are referred to as financial contributions.

The second type of study examines the relationship between unpaid housework and mental health (Bird, 1999; Staland-Nyman,Alexanderson, \& Hensing, 2008). On the one hand, fewer hours spent doing housework and more equity in the division of household labour are associated with improved mental health for both men and women (Bird, 1999; Boye, 2011; Staland-Nyman et al., 2008; Treas, van der Lippe, \& Tai, 2011). In contrast, being a homemaker is related to a lower sense of control (Bird \& Ross, 1993; Ross \& Wright, 1998) and a lack of shared responsibility for household labour increases feelings of inequity, which is also a source of distress in intimate relationships (Bird, 1999; Mirowsky, 1985). On the other hand, Treas et al. (2011) find that homemakers are slightly happier as compared to full-time working wives due to absence of time binds, cultural expectations for mothering, etc. Furthermore, complex housework chores may contribute to higher psychological well-being (Aube et al., 2000). 


\section{Past research on financial AND HOUSEHOLD CONTRIBUTIONS AND MENTAL HEALTH}

Surprisingly, only a few authors have simultaneously investigated the impact of paid and unpaid labour on personal and partner's mental health. First, researchers have examined the effect of women's employment status on depression, while taking household labour into account. Ross, Mirowsky, and Huber (1983) found an effect of women's employment status on depression, moderated by the preferences for the wife's employment of both spouses. During the transitional period from male breadwinner to dualearner households, men's depression scores were high because they had to conquer the feelings of embarrassment or guilt due to having a wife in employment. Variations in women's or men's earnings seemed to have no effect on depression. In contrast, Rosenfield (1992) states that the altering distribution of financial and housework contributions affected well-being, rather than women's employment directly. Women's employment was positive for men's well-being if they did not share in housework and if they earned the greater share of the household income. For women, both studies concluded that elevated depression scores could be attributed to the fact that domestic labour was not shared.

Second, researchers have focused on equity in the division of both paid and unpaid labour. Both Glass and Fujimoto (1994) and Kalmijn and Monden (2011) argue that a more equal distribution of paid and unpaid labour hours is associated with lower levels of depression. However, according to the former researchers, this relationship is mediated by perceptions of equity. Perceived inequity in paid labour increased depressive symptoms for men, as did perceived inequity in performing household labour for women. The studies of Roxburgh (2004) and Boye (2010) indicated no significant effects of equity on men's levels of depression. Roxburgh (2004) argues that more than 10 hours of weekly housework increased women's depression scores, although mediated by time pressure. In contrast, Boye (2010) found that being employed as well as doing housework was associated with higher psychological wellbeing. Too much time in paid work, however, decreased the beneficial effects of unpaid work, and vice versa.

Some reservations can be raised concerning previous findings. First, the mutual interplay between financial and housework contributions operates within a dyad. Therefore, it is also important to take possible partner effects into account (Kenny, Kashy, \& Cook, 2006).Although Ross et al. (1983), Rosenfield (1992), Glass and Fujimoto (1994), and Kalmijn and Monden (2011) used paired data, only the last of these studies included characteristics of the partner in their model. This limitation of the other three studies could have biased their results. Research has shown concordance in health between partners, both for physical (Monden, 2007) and mental health (Desai, Schimmack, Jidkova, \& Bracke, 2011; Siegel, Bradley, Gallo, \& Kasl, 2004; Tower \& Kasl, 1996). An increase in depression scores for one partner has been shown to be associated with elevated depression scores for the other partner, and vice versa (Desai et al., 2011; Siegel et al., 2004). These crossover effects can be strengthened or weakened by characteristics of the intimate relationship, for example marital closeness (Tower \& Kasl, 1996). Furthermore, relational commitment of the partner has been ignored in past research. However, it can be an important factor at play given that it can compensate for some power imbalance (Mirowsky, 1985). A second reservation is that previous research has focused exclusively on routine household tasks (Ross et al., 1983) or has not made a distinction between different types of domestic labour (Boye, 2010; Glass \& Fujimoto, 1994; Kalmijn \& Monden, 2011).

In sum, because of the continuously evolving and changing labour market, more up-todate research that takes these complexities into account is greatly needed. In general, little is known about the strength of the relationship between mental health and both financial and housework contributions. The aim of this study is to step into this void by examining whether depression differs by the type of household and 
to what extent these differences can be attributed to financial and to housework contributions. We use paired data concerning 1054 married or cohabiting couples, based on a subsample of the Panel Study of Belgian Households (PSBH) that was collected in 2001. We expand on previous research by differentiating between three types of household (male breadwinner, one-anda-half-earner and dual-earner). Several studies have included employment status at the individual level (employed vs. unemployed, or fulltime vs. part-time employment), but the type of household at the marriage level is often ignored (Bird, 1999; Ross et al., 1983). Furthermore, following Barnett and Shen (1997), we go beyond the distinction between female and male tasks. Instead, we account for the more routine lowschedule-control household tasks and the less routine high-schedule-control household tasks. Finally, past research is expanded by assessing possible partner effects of depression and relational commitment.

\section{Methods}

\section{Sample}

The PSBH is a representative sample of the Belgian population, which provides detailed information about a wide range of socioeconomic and family sociological topics (PSBH, 2004). Longitudinal data was collected between 1992 and 2002. In the first wave, 8741 respondents aged 16 years or older (4438 different households) were interviewed. Attrition due to follow-up between wave 1 and 10 amounts to $37.4 \%$ (Ottoy, Verstreken, Maynissen, \& Mortelmans, 2004). Throughout the waves, attrition and representativeness were (largely) recovered by the formation and separation of already participating households and by adding new households selected according to a similar sampling procedure to the seventh wave.

We use data from the 10th wave, collected in 2001. The original sample of this wave contained 3067 households and the response rate equals $85.5 \%$. Each partner completed an individual questionnaire. Information about the household characteristics was provided by one of the partners, based on random selection.
Precautions were taken to ensure the anonymity of the respondents (PSBH, 2004). We restricted our analyses to married or cohabiting heterosexual couples aged $18-65$ years $(N=1732)$ of which both partners completed the interview $(85.1 \%, N=1474)$. Only households with a man in full-time employment are included. Households with a househusband $(N=2)$ or with a man employed part-time $(N=30)$ are excluded because of their small number. In addition, households with one or both partners at home because of sickness, retirement or unemployment $(N=311)$ are removed from the sample because models of (in)dependency can be expected to be different in these particular situations (Brines, 1994). Finally, cases with missing information were deleted listwise $(6.8 \%$, $N=77)$. The final subsample consists of 1054 households.

\section{Measures}

\section{Dependent variable}

Unipolar depression is operationalised by using a modified version of the Health and Daily Living Form scale (Moos, Cronkite, Billings, \& Finney, 1985). This scale measures global depression by the frequency of experiencing particular feelings or impressions during the preceding 3 months $(0=$ never; $4=$ often $)$. The 17 symptoms relate to the criteria for the diagnosis of depression as determined by the Diagnostic and Statistical Manual DSM-III-R. For the purposes of this research, two items are omitted. First, the item 'crying easily' is left out because this occurs much less frequently in men (Bracke, 1996). Second, the item indicating 'physical complaints' is dropped because of a lack of validity as a specific depression-related symptom (Wauterickx \& Bracke, 2005). We average the scores on the remaining 15 items to obtain the final depression score. To create complete data for respondents with three or fewer missing items on the depression scale, we use mean substitution. The scale has a good reliability for both men (Cronbach's $\alpha=0.91$ ) and women (Cronbach's $\alpha=0.90)$. Because the frequency distribution of the scale indicates a significant positive skew, the natural $\log$ is employed to avoid violating 
the normality assumption. The log-transformed mean depression score is $0.63(\mathrm{SD}=0.30)$ for men and 0.75 (SD $=0.28)$ for women, a gender difference that is highly significant $(t=-11.907$, $p \leq 0.001)$. For a better interpretation of the logtransformed depression scores, coefficients are multiplied by 100 giving a mean score of 42.00 for men $(0.63 / 1.50$ [= $\max$ score $4 \times 15$ items] $)$ and 50.00 for women $(0.75 / 1.50)$.

\section{Independent variables: Household characteristics}

The main independent variable type of household is based on the employment status of both partners in the household. It refers to the distinction between male breadwinner households $(N=173$; reference category $)$, dual-earner households $(N=579)$ and one-and-a-halfearner households $(N=302)$. All three include a man in full-time employment. With regard to women, male breadwinner households contain a housewife, dual-earner households a woman employed full-time (who works at least 30 hours a week) and one-and-a-half-earner households a woman employed part-time (who works $<30$ hours a week).

Financial dependence is measured following the formula of Sørensen and McLanahan (1987): Income $_{\text {man }} /\left(\right.$ Income $_{\text {man }}+$ Income $\left._{\text {woman }}\right)$ - Income woman $_{\text {IIncome }}+$ Inan $_{\text {man }}+$ Income $\left._{\text {woman }}\right)$. This indicator measures the dependence of both partners on each other's income $(-1=$ the man is $100 \%$ dependent; $0=$ both partners are equally dependent; 1 = the woman is $100 \%$ dependent). Missing values on the income variables (19.5\% for men and $13.9 \%$ for women) are replaced by gender-specific mean scores. A dummy variable is added to control for the effects of this item nonresponse management strategy (mean income score substituted $=1$ ). Because the majority of housekeeping women actually have no or only a small income, the financial dependence score is only relevant for dual-earner and one-and-a-half-earner households. To estimate the effects of household type and financial dependence simultaneously, the dummy variable of household type $(1=$ dualearner/one-and-a-half-earner) is multiplied by the centred variable, financial dependence
(Models 1 and 2, Table 3). Next, we compute separate internal moderators (Mirowsky, 1999) to look more closely at the differences between one-and-a-half-earner and dual-earner (Model 3, Table 3). We use internal interaction effects because measuring financial dependence is not relevant for male breadwinner households. To estimate these interaction terms, the dummies of type of household ( $1=$ dual-earner $)$ and type of household ( 1 = one-and-a-half-earner) are multiplied by the centred variable financial dependence. Equations (1)-(4) in the Appendix illustrate the algorithm. Equations (3) and (4) estimate the mental health effects of being part of a dual-earner or one-and-a-half-earner couple. Male breadwinner households are set as the reference group (Eq. (2)).

With regard to housework dependence, both partners were asked how frequently they performed the following nine housework tasks: Cleaning, shopping, cooking, doing the laundry, gardening, doing paperwork, administration of daily expenses, and administration of bank and savings accounts (never $=1$; always $=4$ ). Following the algorithm of financial dependence (Housework task $_{\text {man }} /$ (Housework task man $_{\text {man }}+$ Housework $\left.\operatorname{task}_{\text {woman }}\right)-$ Housework task $_{\text {woman }} /$ (Housework task $_{\text {man }}+$ Housework task woman $)$ ), the dependence on the other partner for each of the household chores is measured. A distinction is made between the more routine low-schedule-control housework chores - in this case cooking, doing the laundry, administration of daily expenses and cleaning - and the high-schedule-control housework tasks - in this case shopping, gardening, doing paperwork, and administration of bank and savings accounts (Barnett \& Shen, 1997). For both low and high-schedule-control housework chores, we calculate a mean housework dependence. Scores range from -1 (the wife alone does all the chores) to 1 (the man alone does all the chores). Similarly to financial dependence, we estimate the effects of household type and housework dependence simultaneously by employing interaction effects.

The number of children in the household aged younger than 12 and the number of children aged older than 12 are included, including biological 
children, stepchildren, adopted children and foster children.

\section{Independent variables: Individual and partner characteristics}

In addition to the age of the respondent, the level of education is also taken into account using four categories: No/primary education, lower and higher secondary education, and college or university (reference category).

Relational commitment of the partner is measured using a four-item scale measuring the partners' commitment to their relationship. Respondents were asked for the degree to which the following statements described their relationship: 'We do not hide anything from each other,' 'We spend most of our free time together,' 'We usually agree, especially on essential things' and 'We always solve our disagreements very quickly.' Scores on each item range from very bad (=1) to very good (=4). Partner-specific mean scale scores are calculated. The reliability of the scale is 0.76 for women and 0.74 for men.

\section{Analysis methods}

First, we examine the differences by type of household. For the continuous independent variables, the significant differences in mean scores are identified using the one-way ANOVA procedure. For the categorical variables, we look at the percentages and perform a Chi square test to indicate the differences between the household types. Next, since the depression scores of partners are non-independent (Kenny et al., 2006), separate linear regressions are performed for men and women to estimate the log-transformed depression scores by household type. In Model 1, the type of household and the equity measures (financial and housework dependence) are introduced. Model 2 adds the depression scores and the relational commitment of the partner. Finally, Model 3 shows the internal interaction effect of financial dependence. Only significant interaction terms were included in the final model. All the models include age, education level, number of children under and above the age of 12 , and a dummy variable for missing values on the income variable to control for the strategy of mean substitution.

\section{Results \\ Depression by household type}

Table 1 indicates that men in a dual-earner or a one-and-a-half-earner household, compared with men in a male breadwinner household, are significantly more depressed. No significant differences between dual-earner and one-and-ahalf-earner households are found. On average, men's log-transformed depression score is 0.08 less in male breadwinner households than in both dual-earner $(p \leq 0.01)$ households, and 0.09 less than in one-and-a-half-earner households $(p \leq 0.05)$. For a better interpretation of the differences in log-transformed depression scores, the coefficients are multiplied by $100(0.08 / 1.50$ [ $=\max$ score $4 \times 15$ items];0.09/1.50). The scores of dual-earner and one-and-a-half earner households on the depression scale with a maximum score of 100 are respectively 5.0 and $5.7 \%$ higher than the scores in male breadwinner households.

\section{Equity by household type}

Financial dependence is significantly different between dual-earner and one-and-a-halfearner households, and low-schedule-control housework dependence differs between all three household types (Table 2). For high-schedulecontrol housework dependence, no significant differences are found.

In dual-earner households, on average women depend on their partner for an 11\% contribution towards their share of the couple's combined income, while this is $28 \%$ in one-anda-half-earner households. More specifically, in the case of dual-earner households, this means that women's contribution to the household income is $39 \%(50-11 \%)$ and men's contribution $61 \%(50+11 \%)$, and for one-and-a-halfearner households, women's contribution is $22 \%$ $(50-28 \%)$ and men's $78 \%(50+28 \%)$. Therefore, women in dual-earner households still seem to be financially dependent on their partner.

With regard to low-schedule-control housework dependence, it is important to note that in all three household types, women do the larger 


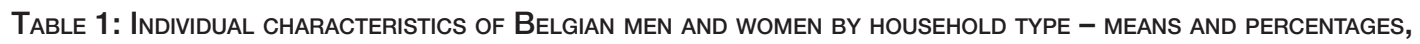
ANOVA AND $X^{2}$-TEST $(N=2108)$

\begin{tabular}{|c|c|c|c|c|c|c|c|c|}
\hline & \multicolumn{4}{|c|}{ Men } & \multicolumn{4}{|c|}{ Women } \\
\hline & $\begin{array}{l}\text { Male- } \\
\text { breadwinner } \\
(N=173)\end{array}$ & $\begin{array}{l}\text { One-and-a- } \\
\text { half earner } \\
(N=302)\end{array}$ & $\begin{array}{l}\text { Dual- } \\
\text { earner } \\
(N=579)\end{array}$ & $F / \chi^{2}$ & $\begin{array}{l}\text { Male- } \\
\text { breadwinner } \\
(N=173)\end{array}$ & $\begin{array}{l}\text { One-and-a- } \\
\text { half earner } \\
(N=302)\end{array}$ & $\begin{array}{l}\text { Dual- } \\
\text { earner } \\
(N=579)\end{array}$ & $F / \chi^{2}$ \\
\hline \multicolumn{9}{|l|}{ Individual characteristics } \\
\hline \multicolumn{9}{|l|}{ Demographic characteristics } \\
\hline Age (mean [SD]) & $\begin{array}{l}46.97 \\
(8.80)\end{array}$ & $\begin{array}{l}41.76 \\
(7.15)\end{array}$ & $\begin{array}{l}40.05 \\
(8.64)\end{array}$ & $* \star \star$ & $\begin{array}{l}45.02 \\
(8.67)\end{array}$ & $\begin{array}{l}39.95 \\
(7.53)\end{array}$ & $\begin{array}{l}37.90 \\
(8.43)\end{array}$ & $* \star *$ \\
\hline Education (\%) & & & & ** & & & & $* \star \star *$ \\
\hline No/primary education & 1.8 & 1.9 & 1.8 & & 2.0 & 1.1 & 1.5 & \\
\hline $\begin{array}{l}\text { Lower secondary } \\
\text { education }\end{array}$ & 3.3 & 5.0 & 10.1 & & 4.6 & 4.6 & 4.3 & \\
\hline $\begin{array}{l}\text { Higher secondary } \\
\text { education }\end{array}$ & 5.3 & 9.9 & 16.6 & & 6.5 & 10.1 & 17.5 & \\
\hline College/university & 6.0 & 11.9 & 26.4 & & 3.3 & 12.8 & 31.7 & \\
\hline Depression (mean [SD]) & $0.56(0.30)$ & $0.65(0.31)$ & $0.64(0.30)$ & & $0.71(0.32)$ & $0.76(0.27)$ & $0.76(0.27)$ & \\
\hline $\begin{array}{l}\text { Relational commitment } \\
\text { (mean [SD]) }\end{array}$ & $3.25(0.50)$ & $3.26(0.49)$ & $3.23(0.49)$ & & $3.27(0.52)$ & $3.27(0.49)$ & $3.21(0.52)$ & \\
\hline
\end{tabular}

${ }^{*} p \leq 0.05 ;{ }^{* *} p \leq 0.01 ;{ }^{* * *} p \leq 0.001$.

TABLE 2: ChARACTERISTICS OF BELGIAN HOUSEHOLdS BY HOUSEHOLD TYPE - MEANS AND ANOVA $(N=1054)$

$\begin{array}{lll} & \text { Household } & \\ \text { Male-breadwinner } & \text { One-and-a-half- } & \text { Dual-earner } F \\ (N=173) & \text { earner }(N=302) & (N=579)\end{array}$

\begin{tabular}{|c|c|c|c|c|}
\hline \multicolumn{5}{|c|}{ Household characteristics } \\
\hline \multicolumn{5}{|c|}{$\begin{array}{l}\text { Demographic characteristics } \\
\text { (mean [SD]) }\end{array}$} \\
\hline Children $<12$ & $0.69(0.104)$ & $0.93(0.97)$ & $0.74(0.94)$ & ** \\
\hline Children $\geq 12$ & $0.98(1.04)$ & $0.85(1.00)$ & $0.62(0.92)$ & *** \\
\hline \multicolumn{5}{|l|}{ Equity (mean [SD]) } \\
\hline $\begin{array}{l}\text { Financial } \\
\text { dependence }\end{array}$ & & $0.28(0.20)$ & $0.11(0.15)$ & *** \\
\hline $\begin{array}{l}\text { Low-schedule- } \\
\text { control dependence }\end{array}$ & $-0.38(0.16)$ & $-0.30(0.16)$ & $-0.24(0.17)$ & *** \\
\hline $\begin{array}{l}\text { High-schedule- } \\
\text { control dependence }\end{array}$ & $-0.02(0.27)$ & $0.01(0.23)$ & $0.01(0.23)$ & \\
\hline
\end{tabular}

${ }^{*} p \leq 0.05 ;{ }^{* \star} p \leq 0.01 ;{ }^{* \star} p \leq 0.001$. proportion of the household chores. In male breadwinner households, men depend on their partner for an additional $38 \%$ of the household labour (therefore $88 \%$ in total), in one-and-ahalf-earner households an additional 30\% and in dual-earner households an additional 24\%.
The bivariate results of our data confirm that men in dual-earner and one-and-a-half-earner households are more depressed than those in male breadwinner households, although only to a our findings suggest that the increase in women's financial independence is accompanied by more sharing of low-schedulecontrol housework chores. We now turn to our main research question and investigate if the differences in depression score by household type could small extent. Furthermore, be attributed to women's financial independence, or to men's share in the low-schedule-control housework chores. In addition, we will investigate if crossover effects of depression between partners mediate these associations and if there is an interaction effect of relational commitment. 


\section{Depression and equity within the household}

Table 3 presents the linear regression models for men and women. For men, Model 1 indicates that being part of a one-and-a-half-earner household is associated with higher depression scores than being part of a male breadwinner household $(b=0.082 ; p \leq 0.01)$. Furthermore, the model shows that doing more low-schedulecontrol housework tasks $(b=0.190 ; p \leq 0.01)$ and having a more financially independent partner $(b=-0.176 ; p \leq 0.01)$ are related to a higher depression level.

Although the mediating factors - i.e., the depression level and relational commitment of the partner - add much to the explained variation in depression levels (Model 2), the independent associations of living in a oneand-a-half-earner household $(b=0.071 ; p \leq 0.01)$, having a financially (in)dependent partner $(b=-0.156$, $p \leq 0.01)$ and doing more low-schedule-control tasks $(b=0.143 ; p \leq 0.05)$ stay significant and their magnitude only diminishes slightly (13.41, 11.36 and $24.74 \%$ respectively). As expected, higher depression scores of men are related to elevated depression scores of their partner $(b=0.298 ; p \leq 0.001)$ and lower relational commitment of the partner $(b=-0.091$; $p \leq 0.001)$.

In the third model, the interaction effects between financial dependence and household

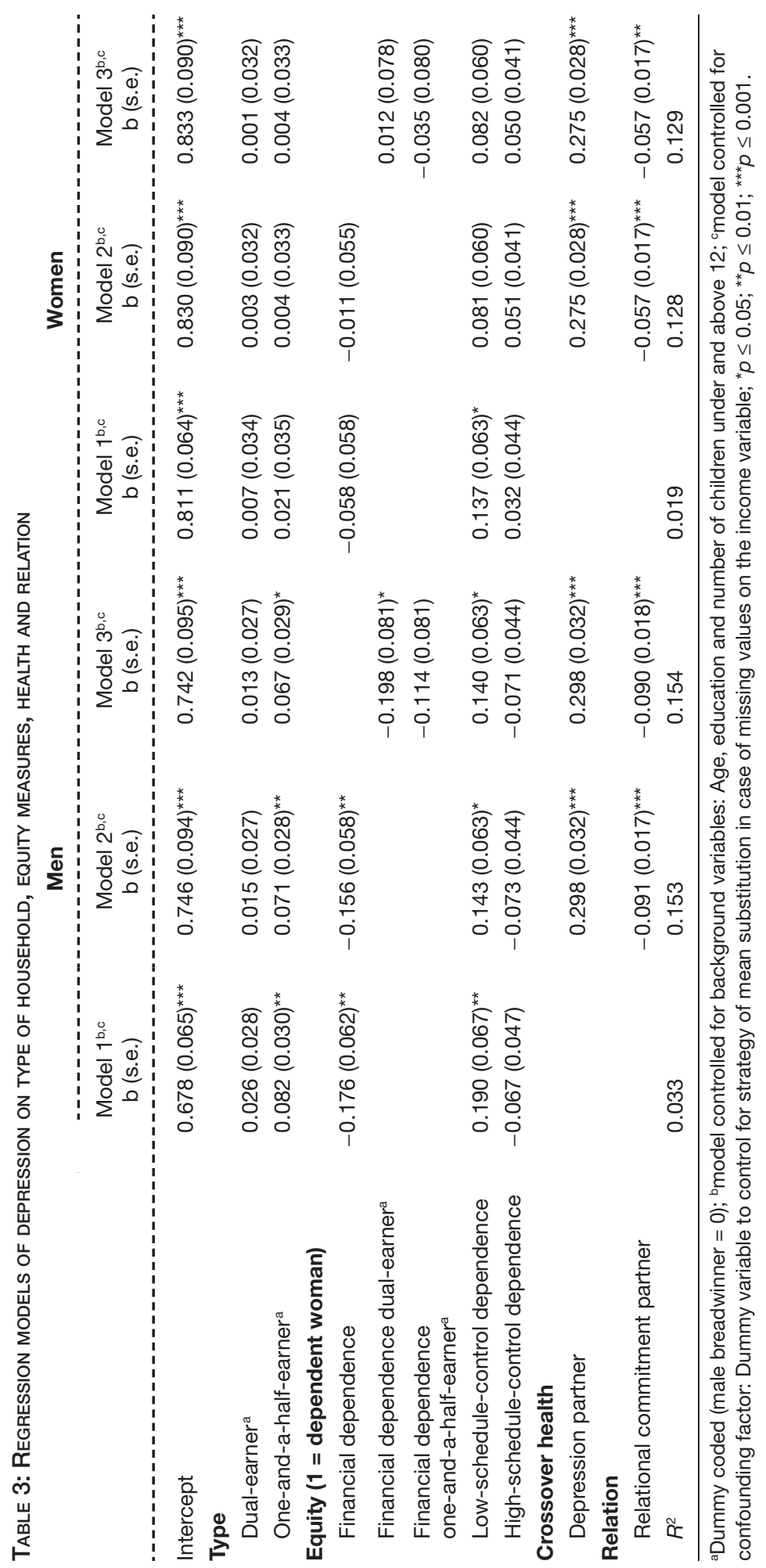

Volume 23, Issue 2, August $2014 \mathcal{H}_{\mathcal{S}_{\mathbb{R}}}$ 
types are examined. With regard to low and high-schedule-control dependence, there is no significant variation by household type so these interaction terms are excluded from the model. We find that men who have a more financially independent partner are more likely to report higher depression scores. However, this association is only significant for men who are part of a dual-earner household $(b=-0.198 ; p \leq 0.05)$.

We now turn to the results for women. Surprisingly, Model 1 shows that doing a smaller proportion of low-schedule-control household chores affects their depression score negatively $(b=0.137 ; p \leq 0.05)$.

With regard to the included mediating factors, Model 2 indicates similar results for women. Depression in the partner is associated with a higher depression level for women $(b=0.275$; $p \leq 0.001$ ), while a higher relational commitment of the partner is related to a decreasing depression level $(b=-0.057 ; p \leq 0.001)$. Interestingly and in contrast to men, the association of low-schedule-control dependence with women's depression scores is fully accounted for by these mediated factors. Additional analyses (results not reported) show that it is the higher depression score of the partner that explains the effect of low-schedule-control dependence.

\section{Discussion AND CONCLUSION}

The aim of this study was to examine the differences in depression scores by various types of household in Belgium. Our main focus is the impact of equity in the division of labour between partners. Previous research is expanded on by estimating the effects of both financial and housework contributions on depression, using paired data from the 10th wave of the PSBH (2004). Several important results are worth noting.

First, our findings show that men who are part of a one-and-a-half-earner household are more likely to report higher depression scores compared with their counterparts in a male breadwinner household. However, in dualearner households men also report higher depression scores, but this association depends upon the level of financial dependence. Since one-and-a-half-earner households are considered as a modern variant of male breadwinner households (Aboim, 2010), men's preferences for women's employment in both households may be alike (Ross et al., 1983). In one-anda-half-earner households, the traditional pattern of the male provider and the female homemaker is eroded. Therefore, it is possible that the men's traditional preferences are not met (Coltrane, 2000), which may lead to higher depression scores. Dual-earner households, on the contrary, are characterised by more egalitarian gender attitudes and more equal sharing of both paid and unpaid labour (Coltrane, 2000). In these households, the idea of one main breadwinner dissolves and women's income cannot longer easily be seen as merely additional (Zelizer, 1989). However, in line with previous research (Rosenfield, 1992), women's employment is positive for men's well-being only if the men still earn the greater share of the household income. Because men in both male breadwinner and one-and-a-half-earner households earn the greater share in household income anyhow, it is not surprising that no effects of financial dependence on depression are found.

Next, our results show a crossover effect of the partner's depression scores for both men and women. This resemblance in mental health is consistent with previous research (Desai et al., 2011; Siegel et al., 2004; Tower \& Kasl, 1996). In addition, our findings suggest that the association between low-schedule-control dependence and women's higher depression scores can be attributed to the crossover effects of the depression level of the partner. Men's greater participation in household chores is associated with higher depression scores, both for a man and his partner. This finding contradicts the many previous results pointing towards the benefits of equally shared housework (Bird, 1999; Boye, 2011; Staland-Nyman et al., 2008; Treas et al., 2011). However, it is in line with the theory of maternal gatekeeping which focuses on the domestic domain as a female sphere of influence in which women prefer to remain in charge (Allen \& Hawkins, 1999). 'Gatekeeping' is often seen as a counterbalance for women's lower pay or status 
outside the home (Gaunt, 2008). Therefore, we can suppose that women, since they generally hold power in the domestic domain, show higher depression scores if this desire is not met.

Finally, the fact that we did not find any direct impact of household type or financial dependence on women's depression is in contrast with previous research in which employment status as well as financial and housework contributions were considered (Glass \& Fujimoto, 1994; Rosenfield, 1992; Ross et al., 1983). Methodological as well as contextual characteristics could help explain our different outcomes. First, this study differed from Ross' et al. (1983) and Glass and Fujimoto's (1994), by not taking any subjective measurements of the division of labour into account. Ross et al. (1983) focused on preferences concerning female employment, while Glass and Fujimoto (1994) included perceived fairness in the allocation of work in their model. Studies that incorporate a subjective approach to the distribution of labour generally indicate stronger effects on mental health because an unequal division of labour is not necessarily perceived as unfair (Greenstein, 2009; Kalmijn \& Monden, 2011). Rosenfield (1992), on the other hand, did not measure mental health in terms of depression, but rather focused on demoralisation, sadness, anxiety, self-esteem, hope/helplessness and insomnia. Second, the past decennia are characterized by a decreasing amount of male breadwinner families and increasingly more female autonomy (Aboim, 2010). In addition, the inconclusiveness of studies about the association between women's employment status and mental health clearly indicates that both being a housewife or a working woman are characterized by particular advantages (Treas et al., 2011). Therefore, we expect that the absence of differences in women's mental health in various household types can be explained by the fact that they nowadays have more say in the decision whether to be part of a traditional vs. a modern household.

Despite the strengths of this study, there are some important limitations we have to bear in mind. The panel study uses a shortened version of the Health and Daily Living Form depression scale (Moos et al., 1985). This scale is not widely used so some caution is needed when comparing our results with findings based on other surveys (Bracke, 2000). Further, we limit mental health to depression. The fact that mental disorders in general are gender related indicates that it can be useful to also take multiple indicators of mental health into account. However, depression is still the leading cause of mental disability (World Health Organisation, 2012). Next, the cross-sectional design hinders causal interpretations. We limited possible selection effects by removing households with one or both partners at home because of sickness, retirement or unemployment from the sample. Households consisting of a partner who was temporary absent from work due to, for instance, maternity leave are included in the analysis, because although these temporary arrangements may influence the division of financial and housework contributions, changes are unlikely to affect longstanding patterns (Brines, 1994). Although the PSBH gathered longitudinal data, the primary aim of this study was to add to an up-to-date 'state of the art' because of the limited amount of previous research. It would be interesting for future research to incorporate a longitudinal dimension to account for prior depressive symptoms and thereby reveal certain dynamics in the evolution of depression (of the partner) and its effects on the distribution of labour in the household. Finally, since the data does not contain absolute measurements of time spent doing household chores, we operationalised household labour as a proportional measurement. Although this is a valid and reliable type of measurement, it has important limitations (Barnett \& Shen, 1997; Marini \& Shelton, 1993). Substantial differences in the amount of time spent in tasks across different households are masked and it remains unclear whether shifts in the proportion result from a change to the contribution of the woman, the man or both (Marini \& Shelton, 1993). As both absolute and proportional measurements have their strengths and weaknesses, it is argued that future research could benefit from using both (Coltrane, 2000). 
To conclude, although employed women nowadays are the rule rather than the exception, the labour market keeps changing and differentiating by variations on part-time employment, working from home, etc. (Margherita, O'Dorchai, \& Bosch, 2009). This increasing complexity and flexibility and the possible consequences for mental health of both men and women requires continued attention and further research into the complex intertwinements between gender, power and mental health in intimate relationships. Our findings show that, in the Belgian population, the mental health status of men is directly associated with a gendered division of paid and household labour. Worse mental health of men goes hand in hand with conditions that signal lower social standing vis-à-vis their partner: Greater financial dependence and taking up low prestige, low-schedule-control tasks. Their partners do not seem to perceive these imbalances as signalling conditions of dependence, lack of standing, lack of competence or lack of control. Nevertheless, their mental health status is linked to their partner's, and as such, women also experience the mental health consequences of relationship interdependencies that are perceived by men as a token of power imbalances. Probably, complex mental health consequences of further shifts in the gendered division of paid and household labour for men and women are to be expected, if both genders hold different views on power and interdependence in intimate relationships, with men focusing on autonomy and control, and women holding on to more relationship-based power strategies (Carli, 1999).

\section{REFERENCES}

Aboim, S. (2010). Gender cultures and the division of labour in contemporary Europe: A cross-national perspective. The Sociological Review, 58(2), 171-196.

Allen, S. M., \& Hawkins, A. J. (1999). Maternal gatekeeping: Mothers' beliefs and behaviors that inhibit greater father involvement in family work. Journal of Marriage and the Family, 61(1), 199-212.

Anxo, D., Fagan, C., Smith, M., Letablier, M., \& Perraudin, C. (2007). Part-time work in European companies: Establishment survey on working time
2004-2005. Luxembourg, Luxembourg: Office for Official Publications of the European Communities.

Aube, J., Fleury, J., \& Smetana, J. (2000). Changes in women's roles: Impact on and social policy implications for the mental health of women and children. Development and Psychopathology, 12(4), 633-656.

Barnett, R. C., \& Shen,Y. C. (1997). Gender, high- and low-schedule-control housework tasks, and psychological distress: A study of dual-earner couples. Journal of Family Issues, 18(4), 403-428.

Bird, C. E. (1999). Gender, household labor, and psychological distress: The impact of the amount and division of housework. Journal of Health and Social Behavior, 40(1), 32-45.

Bird, C. E., \& Ross, C. E. (1993). Houseworkers and paid workers: Qualities of the work and the effects on personal control. Journal of Marriage and the Family, 55(4), 913-925.

Boye, K. (2010). Time spent working. European Societies, 12(3), 419-442.

Boye, K. (2011). Work and well-being in a comparative perspective - The role of family policy. European Sociological Review, 27(1), 16-30.

Bracke, P. (1996). Sex differences in self-reported depression in a representative sample of the Flemish population: The validity of a self-report inventory. Archives of Public Health, 54(7-8), 275-300.

Bracke, P. (2000). The three-year persistence of depressive symptoms in men and women. Social Science $\mathcal{E}$ Medicine, 51(1), 51-64.

Brines, J. (1994). Economic dependency, gender, and the division of labor at home. American Journal of Sociology, 100(3), 652-688.

Carli, L. L. (1999). Gender, interpersonal power, and social influence. Journal of Social Issues, 55(1), 81-99.

Coltrane, S. (2000). Research on household labor: Modelling and measuring the social embeddedness of routine family work. Journal of Marriage and the Family, 62(4), 1208-1233.

Desai, S., Schimmack, U., Jidkova, S., \& Bracke, P. (2011). Spousal similarity in depression: A dyadic latent panel analysis of the panel study of Belgian households. Journal of Abnormal Psychology, 121(2), 309-314.

Eurostat. (2012). Retrieved from http://epp.eurostat. ec.europa.eu

Ferree, M. M. (1991). The gender division of labor in two-earner marriages: Dimensions of variability and change. Journal of Family Issues, 12(2), 158-180.

Franco, A., \& Winqvist, K. (2002). Women and men reconciling work and family life. Statistics in Focus, Population and Social Conditions, 3, 1-7. 
Gaunt, R. (2008). Maternal gatekeeping: Antecedents and consequences. Journal of Family Issues, 29(3), 373-395.

Glass, J., \& Fujimoto, T. (1994). Housework, paid work, and depression among husbands and wives. Journal of Health and Social Behavior, 35(2), 179-191.

Greenstein, T. N. (2009). National context, family satisfaction, and fairness in the division of household labor. Journal of Marriage and Family, 71(4), 1039-1051.

Hakim, C. (1997). A sociological perspective on part-time work. In H. Blossfeld \& C. Hakim (Eds.), Between equalization and marginalization:Women working part-time in Europe and the United States of America (pp. 22-70). Oxford, England: Oxford University Press.

Kalmijn, M., \& Monden, C.W. S. (2011). The division of labor and depressive symptoms at the couple level: Effects of equity or specialization? Journal of Social and Personal Relationships, 29(3), 358-374.

Kenny, D. A., Kashy, D. A., \& Cook, W. L. (2006). Dyadic data analysis. New York, NY:The Guilford Press.

Kessler, R. C., \& McRae, J.A. (1982). The effect of wives' employment on the mental health of married men and women. American Sociological Review, 47(2), 216-227.

Lachance-Grzela, M., \& Bouchard, G. (2010). Why do women do the lion's share of housework? A decade of research. Sex Roles, 63(11-12), 767-780.

Margherita, A., O’Dorchai, S., \& Bosch, J. (2009). Reconciliation between work, private and family life in the European Union. Luxembourg, Luxembourg: Office for Official Publications of the European Communities.

Marini, M. M., \& Shelton, B. A. (1993). Measuring household work: Recent experience in the United States. Social Science Research, 22(4), 361-382.

Mirowsky, J. (1985). Depression and marital power: An equity model. American Journal of Sociology, 91(3), 557-592.

Mirowsky, J. (1999). Analyzing associations between mental health and social circumstances. In C. S. Aneshensel \& J. C. Phelan (Eds.), Handbook of the sociology of mental health (pp. 105-123). New York, NY: Kluwer Academic/Plenum Publishers.

Monden, C. (2007). Partners in health? Exploring resemblance in health between partners in married and cohabiting couples. Sociology of Health and Illness, 29(3), 391-411.

Moos, R. H., Cronkite, R. C., Billings, A. G., \& Finney, J.W. (1985). Health and the daily living form manual, revised version. Stanford, CA: Social Ecological
Laboratory, Veterans Administration and Stanford University Medical Centers.

Orbuch, T. L., \& Custer, L. (1995). The social context of married women's work and its impact on black husbands and white husbands. Journal of Marriage and the Family, 57(2), 333-345.

Ottoy, W.,Verstreken, M., Maynissen, R., \& Mortelmans, D. (2004). Methodebericht. Golf 10 (2001). Wilrijk, Belgium: Steunpunt Gezinsdemografisch Panel, Universiteit Antwerpen.

Panel Study of Belgian Households. (2004). Retrieved from http://www.psbh.be

Parkman, A. M. (2004). Bargaining over housework: The frustrating situation of secondary wage earners. American Journal of Economics and Sociology, 63(4), 765-794.

Rogers, S. J., \& DeBoer, D. D. (2001). Changes in wives' income: Effects on marital happiness, psychological well-being, and the risk of divorce. Journal of Marriage and Family, 63(2), 458-472.

Rosenfield, S. (1992). The costs of sharing: Wives' employment and husbands' mental health. Journal of Health and Social Behavior, 33(3), 213-225.

Ross, C. E., \& Mirowsky, J. (1995). Does employment affect health? Journal of Health and Social Behavior, 36(3), 230-243.

Ross, C. E., Mirowsky, J., \& Huber, J. (1983). Dividing work, sharing work, and in-between: Marriage patterns and depression. American Sociological Review, 48(6), 809-823.

Ross, C. E., \& Wright, M. P. (1998). Women's work, men's work, and the sense of control. Work and Occupations, 25(3), 333-355.

Roxburgh, S. (2004). 'There just aren't enough hours in the day': The mental health consequences of time pressure. Journal of Health and Social Behavior, 45(2), 115-131.

Shelton, B. A., \& John, D. (1996). The division of household labor. Annual Review of Sociology, 22, 299-322.

Siegel, M. J., Bradley, E. H., Gallo, W.T., \& Kasl, S.V. (2004). The effect of spousal mental and physical health on husbands' and wives' depressive symptoms, among older adults: Longitudinal evidence from the health and retirement survey. Journal of Aging and Health, 16(3), 398-425.

Sørensen, A., \& McLanahan, S. (1987). Married women's economic dependency, 1940-1980. American Journal of Sociology, 93(3), 659-687.

Staland-Nyman, C., Alexanderson, K., \& Hensing, G. (2008). Associations between strain in domestic work and self-rated health: A study of employed 
women in Sweden. Scandinavian Journal of Public Health, 36(1), 21-27.

Stier, H., \& Lewin-Epstein, N. (2000). Women's parttime employment and gender inequality in the family. Journal of Family Issues, 21(3), 390-410.

Tower, R. B., \& Kasl, S.V. (1996). Depressive symptoms across older spouses: Longitudinal influences. Psychology and Aging, 11(4), 683-697.

Treas, J., van der Lippe, T., \& Tai, T. C. (2011). The happy homemaker? Married women's well-being in crossnational perspective. Social Forces, 90(1), 111-132.

Vogler, C. (1998). Money in the household: Some underlying issues of power. Sociological Review, 46(4), 687-713.
Wauterickx, N., \& Bracke, P. (2005). Unipolar depression in the Belgian population:Trends and sex differences in an eight-wave sample. Social Psychiatry and Psychiatric Epidemiology, 40, 691-699.

World Health Organisation. (2012). Depression. Retrieved from http://www.who.int/mediacentre/ factsheets/fs369/en/index.html

Zelizer,V.A. (1989). The social meaning of money: 'Special moneys'. American Journal of Sociology, 95(5), 342-377.

Received 14 March 2013 Accepted 27 November 2013

\section{APPENDIX}

\section{Financial dependence}

General equation:

$\log$ [depression score $]=b_{0}+b_{1}$ (type of household) $+b_{2}$ [(financial dependence - average financial dependence) $*$ type of household] $+b_{\mathrm{n}}$ (other variables) $+\varepsilon$

For male breadwinner households (type of household $=0$ ) the equation amounts to

Log [depression score $]=b_{0}+b_{1}(0)$

$+b_{2}$ [(financial dependence - average financial dependence) $* 0]$

$+b_{\mathrm{n}}$ (other variables) $+\varepsilon$
For dual-earner households (type of household $=1$ ) the equation amounts to

$\log$ [depression score $]=b_{0}+b_{1}(1)$ $+b_{2}[$ (financial dependence - average financial dependence) $* 1]$

$+b_{\mathrm{n}}$ (other variables) $+\varepsilon$

For one-and-a-half-earner households (type of household $=1$ ) the equation amounts to

$\log [$ depression score $]=b_{0}+b_{1}(1)$

$+b_{2}$ [(financial dependence - average financial dependence) $* 1]$

$+b_{\mathrm{n}}$ (other variables) $+\varepsilon$

\section{NOW AVAILABLE}

\section{FAmily Studies}

\section{Volume 20 Issue 1 - 1+100 pages - ISSN 1322-9400 - April 2014}

EdITORIAL: The family: What is it, how do we study it and why? - Kay Cook

Pregnant partners: Fathers of the Growing Up in New Zealand children - Jan Pryor, Susan Morton, Dinusha Bandara, Elizabeth Robinson and Cameron Grant

Changes in gender equality? Swedish fathers' parental leave, division of childcare and housework - Anna-Lena Almqvist and Ann-Zofie Duvander

Motherless mothers: Maternally bereaved women in their everyday roles as mothers - Bethwyn Rowe and Bronwyn A Harman

New knowledge about motherhood: An autoethnography on raising a disabled child - C Dawn Zibricky
The psychology of Vietnamese tiger mothers: Qualitative insights into the parenting beliefs and practices of Vietnamese-Australian mothers - Anthony Nguyen, Paul Chang and Jennifer Loh

Examining mediating pathways between financial stress of mothers and fathers and problem behaviour in adolescents Koen Ponnet, Karla Van Leeuwen and Edwin Wouters

DREAMers and their families: A family impact analysis of the DREAM Act and implications for family well-being Duhita Mahatmya and Lisa M Gring-Pemble

Psychological health and provision of grandchild care in noncustodial 'baby boomer' grandparents - Cecily Young and Linley Alice Denson http://jfs.e-contentmanagement.com/archives/vol/20/issue/1/general-issue

eContent Management Pty Ltd, PO Box 1027, Maleny QLD 4552, Australia

Tel.: +61-7-5435-2900; Fax. +61-7-5435-2911;

subscriptions@e-contentmanagement.com www.e-contentmanagement.com 